\section{SUBMISSION OF ARTICLES}

If you want to submit an article for our editors to look at, please send it to:

Editors, Itinerario

P.O.Box 9515

2300 RA Leiden

The Netherlands

Of course, articles may also be submitted through E-mail: send your article to Itinerario@hum.leidenuniv.nl

Authors submitting work to Itinerario are advised to follow the submission guidelines as closely as possible to minimise editorial changes to their work and thus minimise the chance of introducing errors inadvertently into your writing. The guidelines are based on and are similar to the recommendations found in the internationally known and respected Chicago Manual of Style, 15th edition, and readers are encouraged to refer to that work should they require clarification. Likewise, they can always address any particular questions to the editors at Itinerario@hum.leidenuniv.nl.

Submission guidelines can be found at http://assets.cambridge.org/ITI/ITI_ifc.pdf

\section{COPYING}

This journal is registered with the Copyright Clearance Center, 222 Rosewood Drive, Danvers, MA 01923, USA. Organisations in the USA who are also registered with the C.C.C. may, therefore copy material (beyond the limits permitted by, sections 107 and 108 of U.S. Copyright law) subject to payment to the C.C.C of the per copy fee of $\$ 15.00$. This consent does not extend to multiple copying for promotional or commercial purposes. Code 0165-1153/13. ISI Tear Sheet Service, 3501 Market Street, Philadelphia, PA 19104, USA, is authorised to supply single copies of separate articles for private use only. Organisations authorised by the Copyright Licensing Agency may also copy material subject to the usual conditions. For all other use, permission should be sought from Cambridge or from the American Branch of Cambridge University Press.

Cover design: Anton Feddema, Amsterdam Illustration: by courtesy of Rijksmuseum Amsterdam

Effective Vol. 33 (2009), Itinerario - International Journal on the History of European Expansion and Global Interaction, is being covered by the Thomson-Reuters journal citation reports. 


\section{VOLUME 37 | ISSUE 1 | 2013}

\section{Itinerario is afuly referece intenational journal}

published three times a year by Leiden University's Institute for History.

Itinerario is affiliated with the Leiden Institute of Area Studies (LIAS) and the forum on European Expansion and Global Interaction (FEEGI) in the USA.

Itinerario, founded in 1977, offers a publishing platform for research on the history of European Expansion in both its Western and Non-Western contexts, and its impact on World History in general.

For further information: www.itinerario.nl
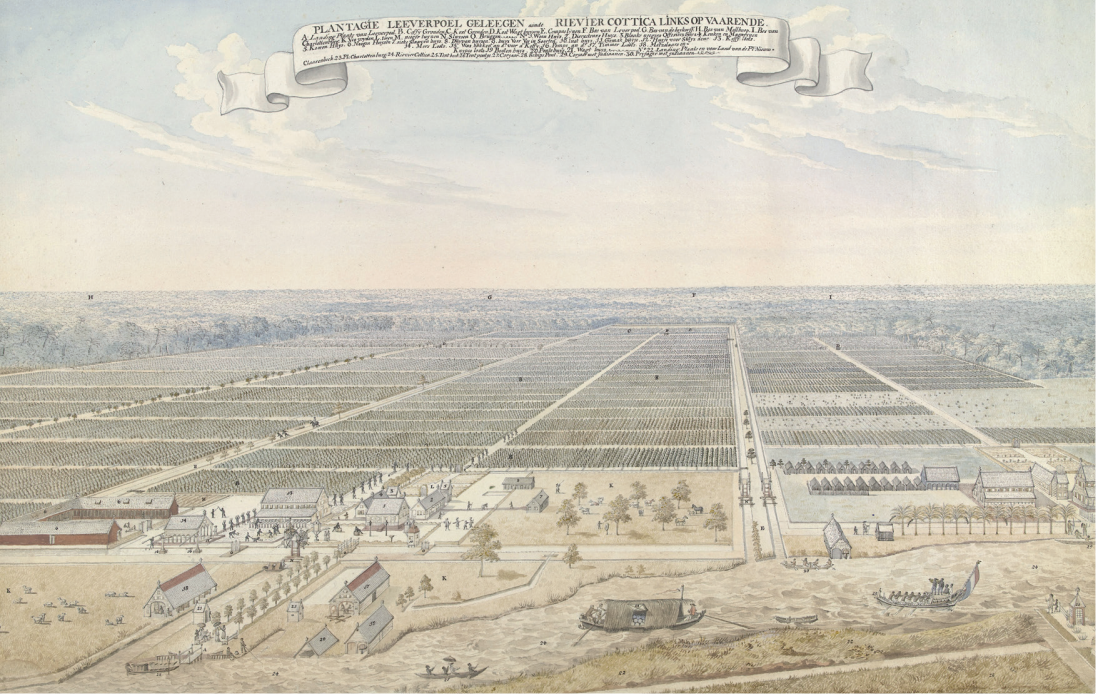

View of the coffee plantation Leeverpoel along the river Cottica in Suriname, around 1800. Anonymous artist. (Dutch title: Plantagie Leeverpoel Geleegen aan den Rievier Cottica linksop vaarende).

With the courtesy of the Rijksmuseum Amsterdam.

Cambridge Journals Online For further information about this journal please go to the journal web site at: journals.cambridge.org/iti

\section{MIX}

Paper from

responsible sources CAMBRIDGE FSC ${ }^{\odot}$ C007785 UNIVERSITY PRESS 